\title{
PESANTREN BERBASIS WIRAUSAHA \\ (Pemberdayaan Potensi Enterpreneurship Santri di Beberapa \\ Pesantren Kaliwungu Kendal)
}

\author{
Abdul Ghofur, Nur Asiyah, dan M Shofiyullah
}

\begin{abstract}
Abstrak: Pemberdayaan masyarakat pesantren berbasis wirausaha ini pada prinsipnya untuk menjembatani permasalahan yang sering dialami santri, khususnya alumninya. Banyak alumni pondok pesantren, meski secara keilmuan relatif berhasil dan diakui di masyarakat, bahkan cenderung ditokohkan di daerahnya masing-masing, namun dalam segi perekonomian, mereka mengalami masalah. Oleh sebab itu diupayakan langkah tertentu, khususnya pemberdayaan potensi entrepreneurship. Pelaksanaan pemberdayaan potensi entrepreneurship yang dilakukan di tiga pondok pesantren di wilayah Kecamatan Kaliwungu Kabupaten Kendal, yaitu PP Miftahul Falah, PP ARIS dan PP ASPIR, setidaknya, dapat menggapai beberapa poin yang dapat menjembatani beberapa permasalahan di atas. Pertama, dengan mengikuti kegiatan ini, para peserta tergugah untuk melakukan kreasi, inovasi dalam merespon kebutuhan masyarakat sebagai sumber perekonomian. Kedua, ada kesadaran dari para peserta bahwa setiap barang dapat dimanfaatkan secara optimal. Ketiga, pentingnya pemanfaatan waktu secara lebih intensif untuk menghasilkan sebuah barang yang bernilai ekonomis dan dapat menjadi peluang income bagi mereka. Keempat, ada kesadaran dari para peserta akan arti pentingnya pemanfaatan lahan-lahan kosong agar lebih berdayaguna dan lebih produktif.
\end{abstract}

Kata Kunci: pemberdayaan, masyarakat pesantren, potensi entrepreneurship, produktif

\section{PENDAHULUAN}

Dipilihnya pesantren sebagai objek sekaligus subjek pengabdian ini antara lain bahwa pesantren merupakan sistem pendidikan tertua di 
Indonesia ${ }^{1}$ yang sebagian besar lulusannya relatif diterima di masyarakat dan kebanyakan mereka menjadi tokoh atau setidaknya ditokohkan. Akan tetapi, dalam kenyataanya banyak lulusan pesantren yang tidak dibekali dengan kemampuan, baik formal maupun non formal, untuk bekerja dalam rangka untuk memenuhi kebutuhan ekonomi dan mata pencaharian mereka. Sehingga pada saat pertama kali 'terjun' di masyarakat, banyak dari mereka yang mengalami 'keterasingan' dan keterjutan terutama dalam bidang ekonomi. Secara historis, pesantren semula merupakan pendidikan agama yang dimulai sejak munculnya masyarakat Islam di negara ini pada abad ke-13. Beberapa abad kemudian penyelenggaraan pendidikan ini semakin teratur dengan munculnya tempat-tempat pengajian yang telah merumuskan kurikulumnya, yakni pengajaran tentang ilmu-ilmu agama Islam. Bentuk ini kemudian berkembang dengan pendirian tempat-tempat menginap bagi para pelajar (santri), yang kemudian disebut pesantren. Meski bentuknya masih sangat sederhana, pada waktu itu pendidikan ini merupakan satu-satunya lembaga pendidikan yang terstruktur, sehingga pendidikan ini dianggap sangat bergengsi.

Di tempat seperti inilah biasanya para santri/ murid memperdalam bahasa Arab sebagai alat untuk memperdalam kitab-kitab kuning yang membahas tentang ilmu fiqh (hukum Islam), ushul fiqh (pengetahuan tentang sumber-sumber dan sistem yurisprudensi Islam), hadist, adab (sastra arab), tafsir, taubid (teologi Islam), tarikh (sejarah Islam), tasawuf dan akblak (etika Islam). ${ }^{2}$ Dari proses pembelajaran pesantren yang demikian, pesantren mempunyai peran strategis dalam kehidupan sosial kemasyarakatan, terutama dalam bidang keagamaan. Karenanya, menurut Karel, ${ }^{3}$ pengajaran agama pesantren membawa pengaruh agamis yang menghasilkan lingkungan yang khas, disiplin dalam menegakkan shalat dan pelaksanaan kewajiban syari'at Islam lainnya.

${ }^{1}$ Lihat KH. Sahal Mahfudh, Nuansa Fiqh Sosial, (Yogyakarta: LkiS, 1994), hlm. 271

2 Zamakhsyari Dhofier, Tradisi Pesantren (Studi tentang Pandangan Hidup Kiai), (Jakarta: LP3ES, 1982), hlm. 20

${ }^{3}$ Karel A. Steenbrink, Pesantren, Madrasah, Sekolah: Pendidikan Islam dalam Kurun Modern, (Jakarta: LP3ES, 1986), hlm. 16. 
Namun zaman telah berubah, banyak tokoh pesantren yang memandang bahwa peran dan fungsi pesantren tidak lagi bisa dipertahankan hanya dengan berkutat dengan subkultur mereka yang hanya mengfokuskan pada 'hanya' engetahuan agama semata. Sebab, sebagaimana institusi pendidikan keagamaan lain, pesantren juga tidak bisa kedap terhadap perubahan (change) dan pembaharuan (reform). Untuk tetap aktif, sudah barang tentu, lembaga pesantren harus melakukan serangkaian transformasi yang disebut dinamisasi dan modernisasi, tak terkecuali dengan pesantren-pesantren yang terdapat di Kaliwungu. Oleh sebab itu, seiring perubahan zaman pondok pesantren perlu lebih diberdayakan dan diperkuat lagi. Sehingga para santrinya diharapkan lebih memiliki mental untuk berkompetisi ketika mereka telah menyelesaikan studinya di pesantren. Salah satu hal penting yang harus diberdayakan adalah potensi jiwa kewirausahaan/ entrepreneurship para santri.

\section{URGENSI PESANTREN DALAM MENGEMBANGKAN WIRAUSAHA \\ Pesantren}

Di Indonesia, ada beberapa istilah yang digunakan untuk menunjuk lembaga pendidikan Islam tradisional di Indonesia. Di Jawa (termasuk Sunda dan Madura) umunya disebut 'pesantren' atau 'pondok' atau 'pondok pesantren'. ' Sedangkan di Aceh, istilah pesantren sering disebut dengan 'dayah' atau 'rangkang' dan di Minangkabau disebut 'surau'. ${ }^{5}$ Perkataan pesantren berasal dari kata dasar santri yang diberi awalan pedan akhiran an, yang berarti tempat tinggal para santri. Menurut Prof. Johns, sebagaimana dikutip Zamakhsyari Dhofier, santri berasal dari bahasa Tamil yang berarti guru ngaji. Zamakhsyari Dhofier juga mengutip CC Bergyang berpendapat bahwa istilah tersebut berasal dari istilah shastri yang dalam bahasa India berarti oang yang tahu buku-buku suci agama Hindu, atau seorang sarjana ahli kitab suci agama Hindu. Kata shastri

${ }^{4}$ Zamakhsyari Dhofier, Tradisi Pesantren: (Studi tentang Pandangan Hidup Kyai), hlm.8. Lihat A Mukti Ali, Beberapa Persoalan Agama Dewasa Ini, (Jakarta: Rajawali Press, 1997), hlm.15

5 M Dawam Raharjo (peny.), Pesantren dan Pembaharuan, (Jakarta:LP3S, 1985), $\operatorname{hlm} .5$ 
beraal dari kata shastra yang berarti buku-buku suci, buku-buku agama atau buku-buku tentang ilmu pengetahuan. ${ }^{6}$

Pesantren juga dapat dipahami sebagai lembaga pendidikan dan pengajaran agama, umumnya dengan cara non klasikal, di mana seorang kiai mengajarkan ilmu agama Islam kepada santri-santri berdasarkan kitab-kitab yang ditulis dalam bahasa Arab oleh ulama abad pertengahan, dan para santrinya biasanya tinggal di pondok (asrama) dalam pesantren tersebut. ${ }^{7}$ Dalam pesantren, santri tinggal dalam kompleks yang biasanya juga menyediakan masjid untuk beribadah, ruang untuk belajar, dan kegiatan keagamaan lainnya. ${ }^{8}$ Kompleks ini biasanya dikelilingi oleh tembok untuk dapat mengawasi keluar masuknya para santri sesuai dengan peraturan yang berlaku. ${ }^{9}$

Lahirnya suatu pesantren, berawal dari beberapa elemen dasar yang selalu ada di dalamnya. Ada lima elemen dasar pesantren yang satu dengan lainnya tidak dapat dipisahkan. Kelima elemen tersebut meliputi kiai, santri, pondok, masjid dan pengajaran kitab-kitab klasik atau sering disebut dengan kitab kuning. ${ }^{10}$

\section{Kewirausahaan}

Wirausaha terdiri dari dua kata yaitu wira dan usaha. Dalam KBBI wira diartikan dengan pahlawan; laki-laki; bersifat jantan (berani), ${ }^{11}$ sedangkan usaha adalah kegiatan dengan mengerahkan tenaga, pikiran, atau badan untuk mencapai suatu maksud; pekerjaan (perbuatan, prakarsa, ikhtiar, daya upaya) untuk mencapai sesuatu; kegiatan di bidang perdagangan (dng maksud mencari untung) ${ }^{12} \mathrm{Jadi}$, wirausaha adalah pejuang atau pahlawan yang berani berbuat sesuatu untuk mencari

${ }^{6}$ Zamakhsyari Dhofier, Tradisi Pesantren (Studi tentang Pandangan Hidup Kiai), hlm.22.

${ }^{7}$ Sudjono Prasodjo, Profil Pesantren, (Jakarta: LP3S, 1982), hlm. 6. hlm.18.

${ }^{8}$ Zamakhsyari Dhofier, Tradisi Pesantren (Studi tentang Pandangan Hidup Kiai),

${ }^{9}$ https://id.wikipedia.org/wiki/Pesantren diunduh pada hari Senin, 29 Juni 2015

10 HM Amin Haedari, Masa Depan Pesantren dalam Tantangan Modernitas dan Tantangan Komplesitas Global, (Jakarta: IRD Press, 2004), hlm.25.

11 http://kbbi.web.id/wira, diunduh sabtu, 1 Agustus 2015, jam 09.39

12 http://kbbi.web.id/usaha diunduh sabtu, 1 Agustus 2015, jam 09.40 
untung.Hendro dalam Baladina mendefinisikan kewirausahaan (enterpreunership) adalah suatu usaha yang kreatif yang membangun suatu value dari yang belum ada menjadi ada dan bisa dinikmati oleh orang banyak. ${ }^{13}$ Sedangkan Agustina mendefinisikan kewirausahaan (enterpreunership) adalah kemampuan berpikir kreatif dan berperilaku inovatif, yang dijadikan dasar, sumber daya, tenaga penggerak, tujuan, siasat, kiat dan proses dalam menghadapi tantangan hidup. ${ }^{14}$

Abdullah Gymnastiar atau yang akrab dengan sapaan Aa'Gym, seorang muballigh dan juga pengusaha sukses dikutip oleh Sudrajat menjelaskan bahwa "entrepreneur adalah kemampuan seseorang untuk mengcreate atau menciptakan manfaat dari apapun yang ada dalam dirinya dan lingkungannya." Aa Gym juga mengatakan "Wirausaha tidak identik dengan bisnis, melainkan keterampilan mengolah potensi yang ada sehingga dapat bermanfaat bagi orang banyak, dalilnya khairunnas anfaubum linnas." "15 Adapun dalil-dalil yang mendukung kewirausahaan antara lain; Q.S. Al Jumu'ah: 10; Q.S. Hud: 61; Q.S. Al-Taubah: 105; Q.S. Al-Ra'd: 11

Suryana mengutip Mc Clleland dalam Agustina mengelompokkan kebutuhan (need) menjadi tiga, yaitu:

1) Need for achievement

Kebutuhan berprestasi dalam wirausaha terlihat dalam bentuk tindakan untuk melakukan sesuatu yang lebih baik dan lebih efisien dibandingkan sebelumnya. Ciri-cirinya adalah: Ingin mengatasi sendiri kesulitan dan persoalan yang timbul pada dirinya; Memerlukan segera umpan balikuntuk melihat keberhasilan dan kegagalan; Memiliki tanggung jawab personal yang tinggi; Berani menghadapi resiko dengan penuh perhitungan; Menyukai tantangan dan melihat tantangan secara seimbang

${ }^{13}$ Nur Baladina, Membangun Konsep Enterpreunership Islam, dalam Jurnal Ulul albab, volume 13 No 2 Tahun 2012, hlm.130

${ }^{14}$ Tri Siwi Agustina, Kewirausahaan; teori dan Penerapan pada wirausaha dan UKM di Indonesia, (Jakarta: Mitra Wacana Media, 2015), hlm.4 hlm. 5-6

15 Sudrajat Rasyid, dkk., Kewirausahaan Santri , ( Jakarta: PT. Citrayudha, 2005), 
2) Need for power

Kebutuhan akan kekuasaan merupakan hasrat untuk mempengaruhi, mengendalikan dan menguasai orang lain. Cirinya adalah keberanian untuk bersaing dan berorientasi pada status.

3) Need for affiliation

Kebutuhan berafiliasi adalah hasrat untuk diterima dan disukai orang lain. Wirausaha yang demikian lebih menyukai persahabatan dan bekerja sama dari pada bersaing yang tidak sehat. ${ }^{16}$

Secara umum tahap-tahap wirausaha adalah:

1) Tahap memulai

Yaitu tahap dimana seseorang yang berniat untuk melakukan usaha mempersiapkan segala sesuatu yang diperlukan, diawali dengan melihat peluang usaha baru yang memungkinkan

2) Tahap melaksanakan usaha

Tahap ini merupakan tahap dimana wirausahawan mengelola berbagi aspek yang terkait dengan usahanya, seperti pembiayaan, sumber daya manusia, kepemilikan, organisasi, kepemimpinan dan lain sebagainya.

3) Tahap mempertahankan usaha

Pada tahap ini, wirausahawan berdasarkan usaha yang telah dicapai melakukan analisis perkembangan yang dicapai untuk ditindaklanjuti sesuai dengan kondisi yang dihadapi.

4) Tahap mengembangkan usaha

Tahap ini merupakan tahap dimana jika hasil yang diperoleh tergolong positif dan mengalami perkembangan atau bertahan, maka perluasan usaha menjadi salah satu pilihan yang mungkin bisa diambil. ${ }^{17}$

16 Tri Siwi Agustina, Kewirausahaan; teori dan Penerapan pada wirausaha dan UKM di Indonesia, hlm.15-16

${ }^{17}$ Tri Siwi Agustina, Kewirausabaan; teori dan Penerapan pada wirausaha dan UKM di Indonesia, hlm.19. 


\section{Signifikansi Pembedayaan Pesantren melalui Wirausaha}

Bekerja dan berusaha termasuk berwirausaha tidak dapat dipisahkan dari kehidupan manusia, karena keberadaannya sebagai khalifah fi al-ardl. Namun, banyak faktor psikologis yang membentuk sikap negative masyarakat terhadap profesi wirausaha, diantaranya: pertam, image bahwa wirausahawan cenderung bersifat agresif, ekspansif, bersaing tidak jujur, kikir dan penghasilan yang tidak stabil. Kedua, pemahaman bahwa ajaran Islam tidak mementingkan kehidupan dunia.Pemahaman seperti itu harus diluruskan.Ialam sangat menghargai wirausaha. Paling tidak, ada dua alasan wirausaha perlu dikembangkan di Indonesia yang mayoritas penduduknya adalah muslim yaiti terbatasnya lapangan kerja dan contoh yang diberikan nabi Muhammad saw, di mana beliau adalah seorang pedagang yang ulet dan terpercaya. ${ }^{18}$

Pentingnya wirausaha sebagai salah satu alternative untuk mengembangkan perekonomian, idealnya, kewirausahaan jangan hanya dikembangkan di dunia usaha, kampus-kampus atau sekolah, tetapi juga di pondok pesantren, termasuk beberapa pondok pesantren yang terdapat di Kaliwungu. Peran penting yang membuat nilai plus dalam pelatihan kewirausahaan di lingkungan pesantren ialah karena mereka tidak hanya mendapatkan ilmu-ilmu wirausaha akan tetapi juga mendapatkan nilainilai keislaman serta suri tauladan yang didapat selama menjadi santri di pondok pesantren. Hal tersebut dapat menjadi modal bagi para santri untuk berwirausaha.

Pelatihan kewirausahaan merupakan salah satu langkah terpenting untuk membangun dan mengembangkan ekonomi bangsa Indonesia.Salah satu masalah mendasar yang hingga kini menjadi tantangan terbesar bangsa Indonesia adalah masalah pembangunan ekonomi. Padahal pembangunan ekonomilah yang akan memberikan pertumbuhan dan kesejahteraan ekonomi suatu bangsa. Dalam hal ini, problem yang dihadapi bangsa Indonesia adalah seiring bertambahnya sumber daya manusia malah justru mengakibatkan bertambah banyak pula pengangguran. Oleh sebab itu, untuk membangun ekonomi

${ }^{18}$ Nur Baladina, Membangun Konsep Enterpreunership Islam, dalam Jurnal Ulul albab, volume 13 No 2 Tahun 2012, hlm.130-131 
Indonesia semakin dirasakan pentingnya peran wirausahawan, karena pembangunan akan lebih berhasil jika ditunjang oleh para wirausahawan yang sukses dalam usahanya. Sebab, dari peran wirausahan inilah akan terbentuk lapangan-lapangan kerja yang variatif. Dalam upaya membuka lapangan kerja baru, maka diperlukan pelatihan kewirausahaan bagi beberapa komponen masyarakat, khususnya di kalangan para santri. Dalam rangka untuk membangkitkan semangat berwirausaha dan menggali potensi, bakat dan minat para santri dalam hal wirausaha inilah Tim KPD atas rekomendasi LP2M UIN Walisongo Semarang menggandeng tiga pondok pesantren di wilayah Kecamatan Kaliwungu Kendal yaitu Pondok Pesantren Miftahul Falah, Pondok Pesantren ARIS, dan pondok pesantren ASPIR untuk mengikuti pelatihan kewirausahan. Peserta tidak hanya dari tiga pesantren tersebut, tetapi juga melibatkan alumni pondok pesantren lain yang, yang saat ini belum bekerja.

\section{PEMBERDAYAAN POTENSI ENTERPRENEURSHIP} SANTRI DI BEBERAPA PESANTREN KALIWUNGU KABUPATEN KENDAL

\section{Profil Pesantren-pesantren Subyek Penelitian di Kecamatan Kaliwungu Kabupaten Kendal}

\section{A. Pondok Perantren ARIS (Arribatul Islamy)}

Pondok pesantren ARIS terletak di kampung Saribaru Kaliwungu.Berdirinya pesantren ini digagas oleh K.H Ahmad Ru'yat dan K.H Humaidullah Irfan.Pesantren ini didirikan oleh K.H Ahmad Dum Irfan, putra dari K.H Irfan dan Ibu nyai Hj. Ruqoyyah. Beliau pernah belajar di Kediri Jawa Timur, pesantren Arjawinangun dan Ciwaringin Cirebon, Jawa Barat. Beliau wafat tahun 1959. Sepeninggal beliau, pesantren diasuh oleh K.H Cholil Hasan dan setelah K.H Cholil Hasan wafat pada tahun 1992, pesantren diasuh oleh K.H Khafidhin Ahmad dum sampai sekarang. Pesantren ini adalah pesantren puteri yang mulanya diinginkan oleh masyarakat dengan alas an: adanya persamaan hak belajar antara laki-laki dan perempuan, semakin banyaknya santri puteri yang datang dan pada waktu itu di Kaliwungu belum ada pesantren puteri.

Pada tahun 1975 dibentuklah Madrasah Mu'allimat Salafiyah yang pembelajarannya dimulai dari Sekolah Persiapan (SP), kelas 1-3 setara dengan Madrasah Tsanawiyah dan kelas 4-6 setara dengan Madrasah 
Aliyah.Adapun kegiatan-kegiatan yang dilaksanakan di PPP ARIS ini adalah:a) Kegiatan belajar mengajar, b) jam'iyyah Barzanji; c) Jam'iyyatul Qurra', d) Jam'iyyah Khithobah; e) Tahlil; f) Rebana; g) Mujahadah; h) Asmaul Husna; i) Lalaran juz 'Amma; j) Semaan Al-Quran; k) Bahtsul Masail; 1) Senam; m) Praktek Ibadah, n) Nariyahan.

\section{B. Pondok Pesantren Miftahul Falah}

Pondok pesantren Miftahul Falah didirikan oleh K.H Ahmad Badawi yang lahir pada tahun $1887 \mathrm{M}$ pada tahun $1918 \mathrm{M}$. Beliau adalah putera dari K.H abdul Rosyid. Beliau berangkat ke Makkatul Mukarromah pada usia 14 tahun untuk mendalami ilmu agama, dengan prioritas mendalami al-Quran. Guru beliau di antaranya adalah Syekh Ubadi Chamdun Insyari as-Shon'ani al-Misri dan Syekh Abdullah bin Ibrahin as-Sunari al-Misri. Dengan Syekh Ubadi inilah beliau mengkhatamkan al-Quran 30 juz bil hifdhi.Beliau juga pernah tabarukan dengan K.H Munawir Krapyak Yoyakarta.Sepulang dari Makkah, K.H Ahmad Badawi melanjutkan mencari ilmu di pesantren Tebu Ireng Jombang yang diasuh oleh K.H Hasyim Asy'ari.K.H Ahmad Badawi wafat pada tanggal 25 Shafar 1397 H bertepatan dengan I Maret 1977 M.

Pesantren ini dilanjutkan oleh putera beliau yang bernama K.H Munawirudin Badawi dan sekarang diasuh oleh Kiai M Ubaidullah Mubarok, putera tertua beliau. Saat ini santri pesantren Miftahul Falah terdiri dari pesantren putera dan puteri. Adapun kegiatan yang dilaksanakan di pondok pesantren adalah: Pengajian al-Quran baik binnadhar maupun bilghaib; Madrasah diniyah; Barzanji; Tahlil; Rebana; dan Semaan al-Quran.

\section{Pondok Pesantren ASPIR}

Pondok pesantren ASPIR didirikan oleh K.H Khudlori Ghozali pada tanggal 26 Desember 1986.Beliau berasal dari Grobogwetan, Pangkah, Tegal. Mulai usia 7 tahun, beliau menimba ilmu di Babakan Ciwaringin Cirebon (1946-1947). Kemudian melanjutkan ke pondok pesantren APIK Kaliwungu (1952-1955) dan APIP Kaliwungu. Beliau wafat pada tahun 2005 saat menunaikan ibadah haji.Saat ini pesantren diasuh oleh K.H Muhsin Ghofur.

Kegiatan yang ada di pondok pesantren ASPIR ini antara lain: a)Belajar mengajar (Madrasah Salafiyah Hudlurul Huda) yang terdiri dari Sekolah Persiapan (SP), Madrasah Tsanawiyah, Madrasah Aliyah dan Takhassus; b) Khitobah; c) Barzanji; d) Tahlil; e) Manaqib; f) Ziarah ke 
makam para wali; g) Rebana; h) Tilawah al-Quran; i) Kaligrafi; j) Hifdhul Quran.

\section{Pelaksanaan Kegiatan Pemberdayaan Potensi Enterpreneurship Santri Di pondok pesantrean ARIS, Miftahul Falah dan ASPIR Kecamatan Kaliwungu Kabupaten Kendal}

\section{A. Persiapan Pelaksanaan Kegiatan}

Pelaksanaan program KPD ini dilakukan dalam rentang waktu kurang lebih 4 (empat) bulan; April, Mei, Juni dan Juli. Pada bulan pertama (April) dilakukan 3 (tiga) hal yaitu melakukan pendekatan pada berbagai pihak, khususnya para pimpinan pesantren, melakukan pendekatan dengan para santri untuk mengetahui karakter serta penggalian bakat dan minat mereka, menghubungi beberapa narasumber dan motivator yang akan mengisi acara pelatihan yang akan dilaksanakan. Pendekatan ini dilakukan dengan cara datang 'sowan' kepada para pengasuh pondok-pondok pesantren terkait mengenai rencana kegiatan pengabdian berupa KPD tersebut; dalam hal ini adalah pengasuh pondok Miftahul Falah bapak Kyai Ubaidullah Munawiruddin Badawi, KH. Khafidzin Ahmad Dum, dan KH.Muchsin Abdul Ghofur dan beberapa pengurus masing-masing pondok pesantren tersebut.

Setelah para pimpinan dan pengurus pondok pesantren tersebut memberi 'lampu hijau', tim KPD melakukan komunikasi dengan para santri untuk mengetahui karakter, minat dan bakat para santri tersebut.Hal ini penting, sebab agar pelatihan yang diadakan memiliki relevansi dengan kebutuhan dan keinginan para santri. Tentu, tidak semua keinginan dan harapan santri dapat kami realisasikan, setidaknya kami mengetahui minat dan bakat serta kesempatan mereka terkait dengan materi pelatihan. Setelah dialog dengan para santri baru kami menentukan dan mencoba berkomunikasi dengan beberapa pihak yang mungkin bisa kami ajak kerjasama dalam merealisasikan program KPD tersebut.

Berdasarkan komunikasi intensif Tim KPD dengan berbagai pihak tersebut, maka ditentukan beberapa bentuk pelatihan sebagai untuk menggali potensi entrepreneurship para santri di ketiga pondok pesantren tersebut.Pelatihan ini, sebenarnya 'hanya' sebagai pintu masuk untuk menggali potensi tersebut.Sebab, dalam realitanya, yang terpenting adalah bagaimana peserta pelatihan dalam mempraktikkan hasil dari pelatihan tersebut serta mengembangkan masing-masing.Setelah melalui diskusi yang 
panjang, maka ditentukanlah beberapa kegiatan: 1) pelatihan Motivasi enterpreneurship/kewirausahaan; 2) Pelatihan Pembuatan Tahu organik bebas limbah dan susukedelai serta aneka ragam makanan dari ampas tahu (serat kedelai) tersebut; 3) Pelatihan pembuatan pita hias pada kerudung; 4) pelatihan pemanfaatan lahan kosong.

\section{B. Pelaksanaan Kegiatan}

Proses pelaksanaan ini, secara umum terbagi menjadi 4 (empat), yaitu:

\section{Pelatihan Motivasi Enterpreneurship/Kewirausahaan}

Pelatihan motivasi entrepreneurship ini dianggap penting, sebab pelatihan inilah yang dapat menggugah 'semangat' seseorang untuk berkarya, berkreasi, melakukan inovasi dalam merespon berbagai tantangan dan hambatan yang datang dari dirinya sendiri maupun alam lingkungan sekitarnya. Hal ini memiliki relevansi dengan apa yang disampaikan Peggy A. Lambing charles R. Kuehl dalam buku Entrepreneurship (1999) yang menyatakan bahwa kewirausahaan adalah suatu usaha yang kreatif yang membangun suatu value dari yang belum ada menjadi ada dan bisa dinikmati oleh orang banyak. Setiap wirausahawan (entrepreneurship) yang sukses memiliki empat unsur pokok, yaitu: 1) Kemampuan (hubungan dengan IQ dan Skill) dalam; membaca peluang, berinovasi, mengelola, dan dalam menjual; 2) Keberanian (hubungannya dengan Emotional Quotient dan mental) dalam: mengatasi ketakutannya, mengendalikan resiko, dan untuk keluar dari zona kenyamanan; 3) Keteguhan hati (hubungannya dengan motivasi diri) yang meliputi: Presistent (ulet), pantang menyerah, determinasi (teguh akan keyakinannya) dan kekuatan akan pikirannya (Powerof mind); 4) Kreativitas yang menelurkan sebuah inspirasi sebagai cikal bakal ide untuk menemukan peluang berdasarkan intuisi (hubungannya dengan experiences). ${ }^{19}$

Pelatihan motivasi entrepreneurship ini ditekankan pada pelatihan motivasi yang diberikan dalam rangka menggugah minat

${ }^{19}$ Hendro, How To Become A Smart Entrepreneurship And To Start A New Busines, (Yogyakarta: Andi Offset, 2005), cet. I, hlm. 18-19 
dan bakat para santri untuk bisa ditumbuhkembangkan dan cinta akan negeri sendiri. Menurut Narasumber, motivasi pertama berasal dari ajaran Islam yang antara lain menekankan bahwa inti sari Allah menciptakan manusia di bumi ini sebagai khalifahnya. Dalam konteks ini Allah menurunkan wahyu melalui para Rasul untuk dijadikan pedoman, baik sebagai agama yang haq (dinul haq) maupun sebagai hudan (petunjuk). Sebagai khalifah fil ardhi, Allah membekali manusia dengan berbagai fasilitas di dunia ini baik yang kasat mata maupun yang tidak terlihat. Dengan berbagai bekal tersebut manusia harus berupaya, bekerja, berkreasi dan senantiasa belajar dalam rangka untuk beribadah dan mendekatkan diri pada Allah SWT. Motivasi kedua berasal diri manusia masing-masing bahwa seseorang itu harus mengembangkan potensi dasar sifat Nabi/Rasul yaitu: Siddiq, Amanah, tabligh, fatonah. Dari potensi dasar Nabi/Rasul inilah para santri hendaknya bisa mengembangkan potensi dirinya, khususnya terkait dengan jiwa dan mental enterpreneurshipnya.

Dalam pelatihan motivasi ini juga ditekankan kecintaan para santri terhadap alam lingkungannya masing-masing karena adanya fakta eksploitasi kekayaan alam yang didominasi oleh Negaranegara asing di negeri Indonesia ini.“Kita boleh berbangga dengan kekayaan alam yang dimiliki oleh Indonesia, tetapi kita juga pasti menangis jika melihat kenyataan bahwa kekayaan alam kita dikuasai oleh asing.Sumber kekayaan alam Indonesia dieksploitasi hanya untuk memenuhi kebutuhan industri Negara-negara maju seperti Amerika, Inggris, Australia, Jepang dan China" demikian menurut narasumber Bapak Muhammad Rois.

Berdasarkan catatan Badan Pemeriksa keuangan (BPK) dominasi asing di sektor Migas 70\%, batu bara, bauksit, nikel dan timah $75 \%$, tembaga dan emas sebesar $85 \%$ serta diperkebunan sawit sebesar 50\%. Jumlah ini menunjukkan bahwa betapa lemahnya posisi pemerintah untuk melindungi aset Negara. Selain itu peran pemerintah untuk mencegah terjadinya konflik agraria di sektor pertambangan juga sangat lemah. Pada tahun 2013 
Konsorsium Pembaruan Agraria (KPA) mencatat ada 38 konflik di sektor pertambangan dengan luas konflik 197.365,90 ha.Di Indonesia ada beberapa gunung yang dikuasai oleh asing dan dijadikan pertambangan. Pertama, Gunung Tembagapura yang ada di Mimika, Papua dikuasai oleh Freeport sejak 1967. Kedua Gunung Meratus yang ada di Kalimantan Selatan dikuasai oleh PT Antang Gunung Meratus (AGM) sejak 1999.Ketiga Gunung Salak yang ada dibogor dikuasai oleh PT Chevron.Keempat, Gunung Pongkor yang dikuasai PT Aneka Tambang (Antam).Kelima adalah Gunung Ciremai yang ada di Jawa Barat yang dikuasai Chevron baru-baru ini dan masih banyak lagi.

Di sisi lain, bahan pangan kita banyak yang disuplai oleh Negara lain dan yang pada saat tertentu kita tidak mudah mendapatkannya, sebut saja kedelai. Ketergantungan pemerintah Indonesia terhadap asing (seperti kedelai dari Amerika Serikatmisalnya) sangat ironi dengan posisi Indonesia sebagai negara agraris.Amerika begitu mudahnya mendapatkan gunung emas di Papua, sedangkan Indonesia mengemis kedelai saja tidak disuplai dengan berbagai alasan.Inilah bukti ketertundukan Indonesia terhadap asing.Ketergantungan terhadap asing yang hanya menguntungkan para kapital, kartel-kartel impor kedelai, dan lainlain. Ini tentu menyadarkan kita akan arti pentingnya membudidayakaan bahan pangan tersebut.

Bahkan lebih ironi lagi, tempe yang berbahan baku kedelai dan telah mendunia, ternyata ada beberapa negara yang telah membuat paten atas produk tempe sesuai ciri khas dinegara tersebut. Dua negara yang sudah mendahului yaitu Amerika Serikat dan Jepang. Jika kelangkaan tempe terus terjadi, berpotensi terjadinya klaim serupa yang dilakukan negara lain seperti Malaysia dan Australia. Tempe khas Jepang pun sudah di produksi dalam kapasitas besar. Inilah bebeerpa tantangan besar yang harus dihadapi oleh generous penerus bangsa, terutama oleh para santri.

\section{Pelatihan Ketrampilan dan Pendampingan}


Pelatihan dan pendampingan ini dilakukan kurang lebih selama 4 (empat), yaitu Mei, Juni, Juli, Agustus. Pelatihan Ketrampilan dilakukan 3 tahap, yakni pada pada 14 Mei 2015; 7 Juni 2015 dan 6 Agustus 2015. Pelatihan ketrampilan yang pertama ini, yakni pada kamis tanggal 14 Mei 2015 di Pondok Pesantren Miftahul Falah yang diikuti oleh sekitar 70 (tujuh puluh) santri dari pondok pesantren Miftahul Falah, Ponpes ARIS dan Ponpes ASPIR serta sebagian dari alumni ponpes Lirboyo Kediri yang berasal dari daerah kaliwungu. Motivator dan narasumber di samping tim KPD ini menghadirkan tim dari LPPNU (Lembaga Pengembangan Pertanian Nahdlatul Ulama) dari Klaten yang dikomandani oleh Bapak Muhammad Rois. ${ }^{20}$ Tim ini sudah sangat professional dalam mendampingi pemberdayaan masyarakat, seperti melakukan pendampingan IKIP Veteran Semarang dalam rangka pemanfaatan lahan kosong sampai saat ini dan lain sebagainya.

Secara umum pelatihan di samping dalam rangka untuk menumbuhkan jiwa kewirausahaan para santri, pelatihan ini juga dikemas dalam rangka untuk memaksimalkan fungsi suatu benda yang kita miliki dengan konsep menghindari "kemubadziran" dan menjaga "kesehatan". Oleh sebab itu pelatihan ini mencoba memfokuskan pada pembuatan makanan yang bebas dari zat kimiawi dan bebas dari dari limbah. Pelatihan ketrampilan dilakukan melalui beberapa tahap yang ditekankan pada pelatihan ketrampilan para santri dalam pembuatan aneka ragam makanan

${ }^{20}$ Bapak Muhammad Rois adalah salah satu Staf dan Trainer Bio Tani Bhahari Indonesia Jakarta 2001 - sekarang dan Trainer IDF and Resolusi Conflic, RACA Institute Jakarta 2000 - skrg, Trainer of TrainingPenataan Produksi, aktivis Pembuatan demplot demplot pertanian, Trauma Hilling korban bencana, Pendiri organisasi tani jawa tengah (ortaja), Penggagas dan pendiri organisasi Petani Mandiri Indonesia pusat, Koordinator Paralegal Jawa Tengah, Pendiri perkumpulan Bakti Suci Klaten, Pendiri gemblung (gerakan masyarakat bangun lumbung), Penggagas dan pengelola Gubug cah angon dan narasumber seminar dan workshop di beberapa negara. 
dengan bahan baku kedelai, bahan baku non-kedelai dan pelatihan pembuatan pita hias pada kerudung.

Pelatihan ketrampilan tahap pertama dilakukan di Pondok Pesantren Miftahul Falah Kapulisen Krajankulon kaliwungu di bawah asuhan Bapak Kyai Ubaidillah Munawiruddin Badawi pada hari Kamis tanggal 14 Mei 2015 bertepatan dengan 25 Rajab 1436 H.Dalam pelatihan tahap pertama ini disampaikan beberapa cara pembuatan tahu organic/magnesium (tanpa bahan kimiawi) dan pembuatan susu kedelai yang ramah lingkungan. Dari ampas tahu/sari kedelai dan sisa air tahu tersebut dibuatlah minuman isotonic (kesehatan)dan perkedel dan beberapa jenis makanan yang lain. Dengan demikian, dari bahan baku kedelai tersebut peserta dapat membuat beberapa macam produk tersebut dengan tanpa limbah, di mana sari kedelai dan ampasnya bisa dijadikan produk-produk makanan yang lain. Dari bahan baku kedelai ini juga dapat dibuat susu kedelai. Adapun tata langkahdilakukan sebagai berikut.

Pelatihan ketrampilan tahap kedua dilakukan di Pondok Pesantren ARIS Kp. Saribaru Krajankulon kaliwungu di bawah asuhan Bapak KH. Khafidhin Ahmad Dum pada hari Ahad tanggal 7 Juni 2015 bertepatan dengan 20 Sya'ban $1436 \mathrm{H}$. Pelatihan tahap kedua ini, di samping melakukan pendalaman tentang motivasi wirausaha dan praktik ulang pembuatan tahu oraganik/magnesium, susu kedelai, minuman isotonic dan perkedel, juga dilakukan pembuatan berbagai makanan yang lain dari berbagai bahan baku seperti ketela pohon, ketelah rambat (ungu) dan dari ampas tahu atau serat kedelai sendiri. Tujuannya adalah agar santri terbekali dengan tambahan ketrampilan, khususnya yang berkaitan dengan pembuatan makanan. Pada Sesi berikutnya para santri diberi wawasan tentang pemanfaatan lahan kosong dengan berbagai cara dan strategi serta kiat-kiatnya.

Pelatihan tahap ketiga adalah pelatihan sulam pita dengan narasumber Wakhidah (anggota PKK Kampung Pesantren, Krajankulon Kaliwungu). 


\section{Pelatihan Pembuatan Tahu Organik, Susu Kedelai, dan Aneka Ragam Makanan Turunannya}

Ada beberapa materi pelatihan yang telah diberikan, terutama terkait dengan pembuatan makanan dari bahan baku kedelai. Dari kedelai ini dapat dibuat berbagai macam makanan bahkan dengan memanfaatkan juga ampas (serat kedelainya). Pelatihan ini relatif menarik, sebab selain memberi ketrampilan, juga memberi wawasan tentang pentingnya ramah lingkungan.

Pertama pembuatan tahu organik. Caranya, persiapkan kedelai dengan cara direndam 4-12 jam dengan takaran 10-12 liter air untuk $1 \mathrm{~kg}$ kedelai dengan catatan tidak boleh menjadi cambah. bahan Sebelum direndam, kedelai dicuci bersih, setelah direndam juga dicuci lagi. Setelah kedelai siap, maka dipersiapkan alat untuk menggiling kedelai tersebut untuk mendapatkan sari kedelai. Salah satu alat penggilingnya bernama tasudo.Cara penggunaannya, sebelum mesin tasudo dihidupkan hendaknya dipersiapkan kapasitas listrik yang memadai. Jika ketersedian watt listrikterbatas maka hendaknya dipersiapkan diesel atau jenset. Jangan lupa disediakan air yang dimasukkan pada tempat tertentu seperti gallon atau yang lain yang airnya bisa mengalur dari tempat/wadah tersebut. Setelah mesin dinyalakan, masukkan kedelai yang telah direndam tadi bersama dengan aliran air dari tempat yang telah disediakan tersebut.

Setelah itu, mesin akan bekerja dan akan menghasilkan air sari kedelai yang telah terpisah dari ampasnya. Agar ampasnya terkumpul dengan baik, maka sebelum mesin dihidupkan kantong plastik perlu dipersiapkan pada tempat keluarnya ampas kedelai tersebut.Setelah berjalan, selanjutnya masukkan kedelai sedikit demi sedikit bersama dengan air yang masuk.Untuk memudahkan prosesnya dan agar lebih lancar, maka hendaknya dibantu dengan menggunakan kayu/galo atau sejenisnya. Dengan alat/mesin tasudo ini, hasil sari kedelainya sudah terpisah dari ampasnya dengan sendirinya. Sebenarnya proses ini juga bisa mesin blender, namun ampasnya harus dipisahkan tersendiri dengan bantuan kain 
saringan tertentu. Di bawah ini adalah proses untuk mendapatkan sari kedelai.

Proses pembuatan tahu berikutnya adalah bahwa setelah air sari kedelai terwadahi dengan baik dan ampasnya terpisah dengan sendirinya, maka langkah berikutnya adalah siapkan panci dan kompor untuk menggodok air kedelai tersebut. Setelah direbus sampai mendidih, diaduk pelan-pelan. Berikutnya, diberi campuran sari bahari dengan ukuran/ perbandingan $1 \mathrm{~kg}$ kedelai dicampur dengan kurang lebih $40 \mathrm{ml}$ sari bahari.Sebelum dituang ke dalam sari kedelai yang sudah mendidih, sari bahari tersebut dicampur/dilarutkan ke dalam air kurang lebih $150 \mathrm{ml}$ air. Masukkan sari bahari yang sudah dilarutkan tadi sedikit demi sedikit sampai terbentuk gumpalan. Sari babari ini memang berfungsi sebagai pengikat sari kedelai untuk diambil sari tahunya. Setelah diaduk secara pelan-pelan dan dimasukkan sari bahari, maka akan muncullah butiran-butiran sari tahu oraganik yang bebas bahan kimiawi yang lama-lama mengumpal.Ambil gumpalan tersebut dan kemudian dimasukkan dalam cetakan tahu yang telah dipersiapkan.Lakukan pengepresan dan pencetakan. Setelah itu dicetak dan mengeras, tahu siap untuk dikonsumsi, tanpa harus digoreng dulu. Dibawah ini adalah gambar gumpalangumpalan sari tahu dan proses pencetakannya.

Kedua Pembuatan susu kedelai. Proses awalnya sama dengan pembuatan tahu, yakni diambil sari kedeleinya melalui mesin tasudo atau mesin yang lain. Setelah air sari kedelai terwadahi dengan baik dan ampasnya terpisah dengan sendirinya, maka langkah berikutnya adalah siapkan panci dan kompor untuk menggodok air kedelai tersebut. Untuk proses pembuatan susu kedelai, air sari kedelai direbus sampai mendidih. Agar rasanya lebih enak maka bisa dicampur dengan sesuatu sesuai dengan selera pembuatnya, seperti jahe atau rempah-rempah yang lain. Setelah selesai, susu kedelai tersebut siap untuk dikemas dan dikonsumsi berdasarkan kebutuhan. Di bawah ini adalah proses 
pembuatan susu kedelai dan susus kedelai yang sudah siap untuk dikemas dan dikonsumsi.

Ketiga pembuatan minuman isotonik. Dari sisa air tahu (setelah diambil gumpalan untuk pembuatan tahun) dibuatlah minuman isotonic (minuman kesehatan) yang sangat berguna bagi kesehatan. Caranya sisa air tahu tersebut tetap di perapian dan diberi berbagai macam rempah-rempah seperti jahe, kayu manis, daun pandan, cengkeh, gula merah, gula pasir dan lain-lain. Komposisinya antara lain sari tahu magnesium 3 liter; daun pandan 4 lembar; serai, geprak 2 lembar; kayu manis dua potong; gula merah $1 / 4 \mathrm{~kg}$; jahe tiga ruas. Berikutnya diaduk secara merata dan setelah dianggap cukup, maka jadilah minuman isotonic yang siap dikonsumsi dan sajikan selagi hangat. Minuman ini sangat bermanfaat untuk kesehatan.

Keempat pembuatan Perkedel. Serat atau ampas kedelai yang telah terpisah tadi bisa dijadikan bahan baku perkedel dengan komposisi antara lain sebagai berikut: serat kedelai 350 gram; ayam cincang 100 gram; sawi hijau 4 lembar rebus diiris tipis; kuning telur 1 butir; 1 butir telur ayam dokocok lepas; bawang merah goreng 2 sendok makan; bawang putih goreng $1 / 2$ sendok makan; minyak goren $500 \mathrm{ml}$; merica bubuk 1/2 sendok; pala bubuk $1 / 4$ sdt. Cara membuatnya; 1) cincang serat tahu, ayam cincang, sawi hijau, tepung, kuning telur, bawang goreng dan semua bumbu. Aduk hingga rata; 2) ambil 1 sendok makan adonan perkedel bentuk sesuai keinginan (biasanya bulat), lakukan hingga adonan habis; 3) Celupkan perkedel ke dalam kocokan telur sampai rata; 4) Panaskan minyak goreng, selanjutnya goreng perkedel hingga matang dan berwarna kuning kecoklatan. Angkat lalu tiris. 5) Perkedel siap disajikan sesuai dengan selera pembuatnya.

Kelima, pembuatan nugget, bahan bakunya dari serat kedelai atau ampas tahu juga. Komposisi lainnya adalah sebagai berikut: serat kedelai 200 gram; daging giling (sapi/ayam) 100 gram; tepung terigu 20 gr; tepung panir/roti 200 gr. Sedang bumbunya terdiri dari: bambang bombay 50 gr dirajang halus; bawang putih 
25 gr; merica dan pala 5 gr; maizena 10 gr; garam secukupnya; telur 2 butir; kecap asin $1 \mathrm{sdm}$; minyak wijen secukupnya; kaldu ayam/sapi bubuk 5 gr; garam dan gula secukupnya. Sementara bahan pencelup (batter)nya terdiri dari: tepung terigu; garam 10 gr, tepung mazena $75 \mathrm{gr}$; baking powder $0,25 \mathrm{sdt}$; lada halus 2,5 gr; air es $250 \mathrm{ml}$. Cara pembuatan batternya bahwa semua bahan dicampur sampai adonan encer. Cara pembuatan naggetnya: 1) siapkan serat kedelai, 2) bawang putih, bombay rajang halus ditumis dan diangkat serta haluskan bersama merica, pala dan garam, 3) campurkan bumbu yang sudah halus dengan serat kedelai (ampas kedelai dan daging giling), 4) aduk sampai rata, lalu masukkan ke loyang dan kukus selama 0,5 jam, 5) angkat dan dinginkan, setelah dingin potong atau cetak sesuai selera. 6) celupkan ke bahan pencelup yang sudah dipersiapkan sebelumnya. Kemudian, lumuri dengan tepung panir dan selanjutnya nugget sudah siap digoreng atau disimpan.

Keenam, pembuatan kue klepon. Dalam hal ini ada kue klepon yang dibuat; kue klepon ubi ungu dan kue klepon yang berbahan baku serat kedelai atau ampas tahu. Kue klepon merupakan kue basah yang sangat khas dari Indonesia.Kue klepon termasuk dalam golongan kue tradisional yang pada umumnya terbuat dari bahan dasar tepung ketan yang dipadukan dengan warna hijau dari air perasan daun suji dan daun pandan juga diberi isi gula merah pada bagian tengahnya.Meskipun kue klepon ini termasuk makanan tradisional yang mungkin terlihat biasa-biasa saja, namun kue klepon ini sudah banyak tersebar sangat luas. Bukan hanya orang kampung yang dapat menggemari kue klepon ini, tetapi orang kota pun ternyata banyak yang suka dengan kue basah yang satu ini. Kue klepon ubi ungu ini sama seperti kue klepon hijau yang terbuat dari tepung ketan dan proses penyajiannya ditaburi dengan kelapa parut. Selain rasa, kue klepon yang terbuat dari ubi ungu ini tentu saja terlihat berbeda dari segi warnanya namun memuliki rasa yang sama-sama enak juga memiliki tekstur yang berbeda. 
Bahan-bahannya adalah sebagai berikut: 300 gr ubi ungu, 65 gr gula merah (disisir halus), 120 gr tepung tapioca (biasaya tepung ketan), 1/2 sendok teh garam $90 \mathrm{ml}$ air hangat, kelapa parut secukupnya (untuk taburan), sedikit garam halus (dicampur dengan kelapa parut), air untuk merebus secukupnya. Cara pembuatannya: 1) Kupas kulit ubi ungu lalu dicuci sampai bersih, 2) Kukus ubi ungu sampai benar-benar matang dan empuk lalu dihaluskan, 3) Campurkan tepung tapioca (biasanya tepung ketan), garam dan ubi ungu, 4) Tuang air sedikit demi sedikit sambil diuleni hingga kalis dan mudah dibentuk, 5) Ambil sedikit adonan lalu diisi dengan gula merah dan dibentuk bulat (lakukan sampai selesai), 6) Panaskan air hingga mendidih lalu masukkan kue klepon yang sudah dibentuk bulat, 7) Rebus kue klepon sampai matang dan kenyal lalu diangkat sambil ditiriskan, 8) Kukus kelapa parut yang sudah dicampur dengan garam kira-kira selama 5-10 menit, angkat, 9) Gulingkan kue klepon dengan kelapa parut hingga merata dan siap dinikmati. Adapun yang berbahan baku serat kedelai atau ampas tahu, tinggal mengganti posisi dari ketela ungunya diganti dengan serat kedelai tersebut.

Ketujuh, pembuatan steak tahu.Mungkin sedikit berbeda dengan steak yang berbahan daging namun rasa dari steak tahu ini tidak kalah enak dengan steak daging. Bahan Yang Digunakan: kurang lebih 400 gram tahu dipotong kecil-kecil, 2 sendok makan margarine, 1 batang bawang perai, ambil bagian hijaunya, tumis. Bumbu: 2 siung bawang putih haluskan, 1 sendok teh kaldu bubuk, 4 sendok makan saus barbecue, 1 sendok teh air jeruk nipis, 1 sendok teh merica bubuk, $50 \mathrm{ml}$ air. Cara Membuat Steak Tahu: 1) Bumbu:Campur semua bahan bumbu menjadi satu, aduk hingga tercampur rata, 2) Lumuri potongan tahu dengan bumbu, ratakan. Diamkan selama kurang lebih 30 menit hingga bumbu meresap. Panaskan pan pemanggang anti lengket bersemir maragarin tipis. Masak tahu satu persatu berserta bumbu peredamnya sambil sesekali dibalik hingga matang dan berwarna kecokelatan.Angkat, letakkan dalam piring saji. 
Kedelapan, pembuatan keripik singkong. Memang bukan berbahan baku kedelai, tetapi berbahan baku alamaiah, singkong yang memang memasyarakat di desa-desa. Caranpembuatannya singkong dikupas,lalu cuci bersih.Selanjutnya singkong dirajang dengan alat perajang untuk mendapatkan ukuran seragam dan tipis.Siapkan air yang dicampur dengan kapur sirih.Masukkan bumbu halus (bawang putih dan garam) ke dalam campuran air dan kapur sirih.Aduk rata. Singkong rajangan direndam ke dalam larutan tersebut selama kurang lebih 30 menit. Angkat dan tiriskan.Berikutnya minyak sayur dipanaskan, selanjutnya, kita memasukkan keripik singkong, aduk-aduk lagi sampai merata.Kemudian, kita angkat dan tiriskan.Biarkan keripik singkong sampai dingin.Untuk membuat keripik singkong yang renyah dan empuk ada triknya. Singkong segar yang sudah direndam, kita keringkan, tapi tidak boleh terkena sinar matahari langsung. Setelah singkong benar-benar kering, kita mempersiapkan dua penggorengan.

Penggorengan yang pertama berisi minyak dengan suhu sedang.Penggorengan ini dipakai untuk menggoreng irisan singkong hanya sampai setengah matang.Sedangkan penggorengan kedua berisi minyak dengan suhu yang panas maksimal.Penggorengan kedua ini digunakan untuk menggoreng irisan singkong hingga matang.

\section{Pelatihan Ketrampilan Pembuatan Sulam Pita Pada Kain, Kerudung, dan Lainnya.}

Sulam pita adalah salah satu teknik menghias kain dengan cara menjahitkan pita secara dekoratif ke atas benda yang akan dihias sehingga terbentuk suatu desain hiasan baru dengan menggunakan berbagai macam tusuk-tusuk hias. Kerajinan sulaman pita sebenarnya merupakan seni yang telah berusia ratusan tahun. Sulam pita atau ribbon embroidery sudah dikenal sejak pertengahan abad 17, dimana pada saat itu sulaman pita tidak hanya digunakan untuk menghias busana tetapi juga untuk 
menghias tas tangan, kerudung, selendang, payung, dan berbagai peralatan rumah tangga. ${ }^{21}$ Di Negara Perancis, sulam pita dipakai untuk memperindah gaun yang dipakai oleh para bangsawan di sana.

Sulaman pita, kini makin meluas pemakaiannya, di antaranya pada tas dan pernik-pernik hiasan rumah tangga seperti sarung batal dan taplak meja. Juga untuk sesuatu yang dipakai di badan seseorang seperti kerudung, mukena, baju dan lain sebagainya. Demikian pula elemen yang digunakan semakin beragam dengan desain yang semakin bagus. Di Indonesia, setiap daerah mempunyai ciri-ciri yang berbeda, ada daerah yang menyukai sulaman-sulaman dengan pola kecil-kecil. Sedang di daerah lain dengan desain yang lebih besar. Akhir-akhir ini dikenal sulam pita model melayu, di mana digunakan sulaman dengan dengan desain bunga yang relatif besar-besar dan bergradasi, seperti bunga mawar. Pola ini disukai tidak hanya di Indonesia, tetapi juga di negara Malaysia dan Singapura.

Pelatihan sulam pita ini dilakukan di pondok pesantren putri Aribatul Islamiyah (ARIS) dengan jumlah peserta ssekitar 40 santri.Pelatihan sulam pita ini, dimaksudkan agar potensi kreasi santri lebih dapat dioptimalkan lagi. Adapun peralatan yang dibutuhkan, antara lain; 1) jarum khusus sulam pita, 2) jarum jahit, 3) gunting, 4) pembidangan, 5) alat tulis karbon. Memang, dalam ketrampilan sulam pita ini, jarum yang digunakan ada dua macam; jarum pita dan jarum sulam biasa. Jarum pita yaitu jarum khusus pita yang lubangnya cukup besar sehingga pita besar bisa masuk melalui lubang tersebut. Jarum yang cocok digunakan adalah jarum chenille. Jarum tajam dengan batang besar dan lubang lebar dengan nomor 15-18. Jarum sulam biasa, lubangnya jauh lebih kecil dibandingkan dengan jarum pita dan dipergunakan untuk menyulam batang/ranting dengan mempergunakan benang sulam.

${ }^{21}$ http://doninovalinda.blogspot.com/2012/03/cara-membuat-sulam-pita.html diunduh pada hari Ahad, 9 Agustus 2015 
Jarum ini juga dipergunakan untuk menjahit akhir sulaman dengan menggunakan benang jahit.

Sementara itu, ada beberapa bahan yang harus dipersiapkan terlebih dahulu, antara lain; pita, benang, dan aneka jenis kain. Jenis dan ukuran pita sesuai dengan selera pembuat/pengrajinnya. Untuk aplikasi sulam pita ini, jenis pita yang digunakan ada beberapa jenis, antara lain; pita satin, organdi, serta sutra. Biasanya yang banyak digunakan adalah pita satin. Selain cukup murah, pita satin lebih awet dan tidak mudah rusak. Sementara pita organdi biasa digunakan oleh para penyulam yang sudah ahli, karena proses penyulamannya harus tepat sehingga tidak mudah rusak. Benang digunakan untuk membuat tangkai atau sulur dan membuat simpul pada akhir pembuatan sulaman. Sedangkan jenis kain yang dapat dipergunakan antara lain; kain shantung, kain katun, raw silk, kain belacu, organdi, moskreb, chiffon, satin, taffeta atau kain apapun yang sesuai dengan selera pembuat.

Persiapan menyulam diawali dengan pembuatan gambar pada kain yang akan disulam. Namun untuk menggambar dikain ini hendaknya diawali dengan menggambar motifnya dulu di kertas sebagai sketsa.Gunakan pensil jahit saat membuat sketsa gambar di kain. Caranya gambar motif di kertas, letakkan letakkan karbon di atas kain, timpah dengan kertas yang sudah ada pola.Sematkan jarum pentul di ujung kertas agar kertas tidak bergeser. Tindas motif sulam pada kertas dan akan tergambar pada kain.

Adapun cara atau teknik dasar sulam pita antara lain sebagai berikut: a) Stem stich (tusuk sulam batang). Stem stich digunakan untuk membuat batang, ranting, atau tangkai bunga dan daun. Stem stich menggunakan benang sulam; b) Straight stich (tusuk sulam tegak). Straight stich mempergunakan pita ukuran $1 / 4$ inchi. Sangat simpel, dengan teknik ini berbagai macam bunga dapat dibuat disesuaikan dengan bentuk masing-masing bunga. c) Ribbon Stich (tusuk sulam pita). Ribbon Stich mempergunakan pita organdi ukuran $1 / 2$ inchi. Sama seperti teknik straight stich, berbagai 
macam bentuk bunga dapat dibentuk melalui teknik ribbon stich. Karena teknik menusuk kedalam dua media kain dan pita maka sebelum menusuk jarum, gunakan besi runcing untuk memperlebar serat pita atau kain sehingga pita mudah masuk. d) Lasy Daisy (tusuk sulam aster/kuncup). Lasy Daisy mempergunakan pita organdi ukuran 1/4 inci; e) Spider Web Rose (tusuk sulam mawar anyam). Spider Web Rose mempergunakan benang sulam atau benang jahit (dirangkap) sebagai kerangka labalabanya, pita yang dipergunakan organdi ukuran $1 / 8$ inci; f) Straight Leaf Stitch (tusuk daun tegak). Straight Leaf Stitch mempergunakan pita organdi ukuran $1 / 8$ inci dan beberapa motif yang lain.

Para santri antusias memperhatikan dan mencermati arahan dari tutor dan narasumber. Hal ini dapat dimaklumi, karena selama ini mereka jarang mendapatkan materi ketrampilan, Sebab, senantiasa disibukkan dengan kehidupan keseharian,

\section{Pelatihan Kiat Memanfaatkan Lahan Kosong Untuk Bisnis}

Pada sesi berikutnya disampaikan beberapa hal yang terkait dengan pemanfaatan lahan kosong agar bisa lebih produktif. Salah satu kiat menjadi kaya raya sebagaimana diajarkan oleh Robert T Kiyosaki dalam buku best seller dunia Rich Dad Poor Dad dijelaskan bahwa orang kaya selalu menghindari liabilitas yakni mengeluarkan uang, justeru mereka berupa mengumpulkan asset sebanyak-banyaknya yakni sesuatu yang menghasilkan uang. Jika kita memiliki tanah/lahan kosong yang tak terpakai sama sekali atau nganggur maka itu merupakan liabilitas karena kita mesti mengeluarkan uang untuk membayar pajak. Padahal, orang kaya adalah orang yang mampu mengubah liabilitas menjadi asset.Agar lahan kosong itu menjadi asset yang menghasilkan uang, maka kita harus memanfaatkan lahan kosong tersebut untuk bisnis. 
Bercocok tanam dengan menggunakan sistem verticultur $^{22}$ (pot bertingkat) merupakan solusi atau jawaban bagi yang berminat dalam budidaya tanaman namun memiliki ruang atau lahan sangat terbatas. Vertikultur bisa diartikan sebagai budi daya tanaman secara vertikal sehingga penanamannya dilakukan dengan menggunakan sistem bertingkat.Tujuan vertikultur adalah untuk memanfaatkan lahan yang sempit secara optimal. Banyak orang yang tidak sadar bahwasanya lahan kosong bisa dijadikan profit kalau bisa mengolahnya. Lahan kosong yang cuma ditumbuhi ilalang,rumput dan dibiarkan liar adalah mubadzir. Padahal kalau kita kreatif lahan tersebut bisa dimanfaatkan dengan baik dan menghasilkan profit.Lahan sempit biasanya ada disekitar rumah, luas lahan hanya beberapa meter saja.Akan tetapi ada beberapa hal yang dapat dilakukan untuk mengembangkan lahan sempit tersebut untuk menghasilkan profit.

Jenis tanaman yang dapat ditanam dengan sistem ini sangat banyak, misalnya a) tanaman sayur dan buah-buahan semusim seperti: sawi,selada, kubis, wortel, tomat, terong, cabai dan lainlainnya, b) tanaman bunga seperti anggrek, mawar, melati, azalea, kembang sepatu, dan lain-lain; dan c) tanaman obat-obatan. Karena harus ditumpuk ke atas, maka diperlukan media tanam berupa pot dari paralon atau polybag. Namun, sebenarnya media tanam sistem vertikultur tidak terbatas pada paralon dan polybag saja.Masih banyak benda-benda yang ada di sekitar kita yang dapat dimanfaatkan dengan menggunakan beberapa media seperti; prolon, bambu, talang air, botol bekas dan lain-lain.

Kelebihan sistem pertanian vertikultur: (1) Efisiensi dalam penggunaan lahan. (2) Penghematan pemakaian pupuk dan pestisida. (3) Dapat dipindahkan dengan mudah karena tanaman diletakkan dalam wadah tertentu. (4) Mudah dalam hal

${ }^{22}$ Vertikultur berasal dari bahasa inggris, yaitu vertical dan culture.vertikultur adalah suatu teknik bercocok tanam diruang sempit dengan memanfaatkan bidang vertikal sebagai tempat bercocok tanam yang dilakukan secara bertingkat.Diunduh dari http://nurfahmiakhmad96.blogspot.com/2013/08/pengertian-dan-manfaatvertikultur.html pada hari Senin tanggal 6 Juli 2015. 
monitoring/pemeliharaan tanaman. Namun demikian, sistem budidaya vertikultur juga memiliki kelemahan, yaitu: (1) Investasi awal cukup tinggi. (2) Sistem penyiraman harus kontinyu serta memerlukan beberapa peralatan tambahan, misalnya tangga sebagai alat bantu penyiraman, dan lain-lain.

Lahan kosong ini juga bisa dijadikan budidaya ternak binatang seperti ayam,baik ayam kampung atau ayam petelur. Bisa juga dapat untuk ternak kelinci atau dibuat kolam ikan dan lainlain. Demikian juga pemanfaatan lahan sempit juga dapat dilakukan dengan sistem kombinasi yaitu dengan beternak ayam sekaligus bertanam mangga atau pisang.maka keuntungan dobel yang didapat,kita bisa mendapatkan profit dari ayam dan memanen buah mangga atau pisang,kalaupun ayam tidak bertelur maka masih ada mangga dan pisang.masih banyak potensi yang bisa dikembangkan di lahan sempit ini yaitu dengan menanam sayuran seperti tomat,cabe,sayuran sawi atau kangkung. Hal ini terkait dengan pembuatan media tanam.

Media tanam merupakan salah satu factor penting dan sangat menentukan dalam kegiatan bercocok tanam di mana media tanam ini akan sangat menentukan baik buruknya pertumbuhan tanaman yang mempengaruhi hasil produksi. Ada banyak ragam material yang bisa dimanfaatkan untuk media tanam mulai dari alami hingga yang sintetis. Akan tetapi, dalam konteks ini, akan disampaikan beberapa bahan organic yang memang banya tersedia di alam, di samping harganya murah dan mudah pembuatannya.

Untuk membuat media tanam yang baik diperlukan unsur tanah, bahan pengikat atau penyimpan air dan penyedia unsur hara. Bahan baku yang digunakan adalah tanah top soil (tanah bagian lapisan atas), kompos dan arang. Caranya sebagai berikut: siapkan tanah yang terlihat gembur dan subur, lebih baik diambil dari bagian paling atas. Kemudian ayak tanah tersebut hingga menjadi butiran-butiran halus.Ushakan tanah dalam keadaan kering sehingga tidak menggumpal. Sebab, tanah yang 
menggumpal akan menyebabkan bahan-bahan tidak tercampur dengan merata. Siapkan kompos atau humus yang telah matang, bisa dari jenis kompos biasa, bokashi atau kompos takakura.Ayak kompos atau humus tersebut sehingga menjadi butiran-butiran halus.Siapkan arang sekam ${ }^{23}$ yang memiliki manfaat untuk menetralisir keasaman tanah, menetralisir racun, meningkatkan daya ikat tanah terhadap air, merangsang pertumbuhan mikroba yang menguntungkan bagi tanaman, menjadikan tanah gembur sehingga memperbaiki drainase dan aerasi tanah. Campurkan tanah, kompos dan aram sekam dalam sebuah wadah. Komposisi campuran adalah 2 bagian tanah, 1 bagian kompos, dan 1 bagian arang sekam (2:1:1), aduk hingga merata. Ketiga bahan baku tersebutbisa juga dicampur dengan komposisi (1:1:1), mana yang tebaik bagi penggunanya, tergantung dari jenis tanaman dan ketersediaan sumber daya. Berikutnya, siapkan pot atau polybag, masukkan campuran tersebut ke dalamnya dan media tanampun sudah siap untuk digunakan.

Seiring dengan berkembangnya berbagai metode bercocok tanam, ada berbagai jenis media, antara lain hidroponik dan aeroponik. Hidroponik ${ }^{24}$ dalam realitasnya lebih banyak diminati dan menjadi trend tersendiri.Hidroponik juga dikenal sebagai soilless culture atau budidaya tanaman tanpa menggunakan media tanah.Jadi hidroponik berarti budidaya tanaman yang memanfaatkan air dan tanpa menggunakan tanah sebagai media tanam atau soilless.Menanam dengan teknik hidroponik berarti kita bercocok tanam dengan memperhatikan pada pemenuhan kebutuhan nutrisi bagi tanaman yang bersangkutan, atau istilah

${ }^{23}$ Aram sekam merupakan hasil pembakaran tidak sempurna dari padi.Arang sekam berguna untuk meningkatkan kapasitas porositas tanah. Lihat Dr. H. Bambang Triono dkk, Kaya dari Rumab; Panduan Mengembangkan Bisnis dari Rumah (Industri rumahan), Jember: Penerbit Cerdas Ulet Kreatif, 2015, hal. 40.

${ }^{24}$ Kata Hidroponik berasal dari bahasa Yunani yaitu "hydro" yang berarti air dan "ponics" yang artinya daya atau tenaga atau tenaga kerja. Jadi menanam dengan sistem hidroponik artinya menanam menggunakan media air atau tenaga kerja air.Lihat http://www.azzamrumahherbal.com/hidroponik/191-cara-menanam-menggunakansistem-hidroponik.html diunduh pada hari Senin tanggal 6 Juli 2015. 
lainnya bercocok tanam tanpa tanah tetapi menggunakan air yang mengandung nutrisi yang dibutuhkan tanaman.Rupanya masyarakat sudah menyadari pentingnya kebutuhan pupuk bagi tanaman. Di mana pun tumbuhnya sebuah tanaman akan tetap dapat tumbuh dengan baik apabila nutrisi (unsur hara) yang dibutuhkan selalu tercukupi. Dalam konteks ini peranan tanah adalah untuk penyangga tanaman dan air yang ada merupakan pelarut nutrisi, untuk kemudian bisa diserap tanaman.

Sedangkan mengenai langkah-langkah menanam dengan sistem hidroponik antara lain sebagai berikut: Pertama, Tentukan tanaman apa yang akan kita tanam. Menentukan jenis tanaman yang akan kita tanam sangat penting karena menyangkut berbagai hal yang berkaitan dengan penyediaan tanaman dengan menggunakan sistem hidroponik. Misalnya saat kita akan menanam cabe, tentunya kita harus perhatikan perlakukan khusus pada tanaman cabe, seperti cara menyemai, nutrisi cabe, pencahayaan, suhu udara, oksigen terlarut, ajir atau penyangga, sismtem hidroponik yang dipakai, teknik pemotongan/ pemangkasan (pruning), hama cabe, tanaman pendamping dan lain-lain. Lain halnya pada saat kita menanam pokcoy, sawi atau kangkung atau sayur lainnya.

Kedua, Tentukan sistem hidroponik yang akan dipakai, apakah menggunakan sistem wick, ${ }^{25}$ sistem fertigasi, ${ }^{26}$ sistem NFT, ${ }^{27}$ dan lain-lain. Biasanya untuk tanaman sejenis sayuran seperti selada, sawi, pokcoy, dan lain-lain banyak menggunakan

${ }^{25}$ Wick system adalah metode hidroponik yang menggunakan perantara sumbu antara nutrisi dan media tanam. Diunduh dari https://harusketemu.wordpress.com/tag/hidroponik-sistem-wick/ pada hari Senin 6 Juli 2015

${ }^{26}$ Sistem Fertigasi ialah salah satu dari metode hidroponik. Fertigasi adalah teknik aplikasi unsur hara melalui sistem irigasi. Diunduh dari http://griyahidroponik.blogspot.com-/p/fertigasi.html hari Senin tanggal 6 Juli 2015

${ }^{27}$ Hidroponik NFT adalah pengerjaan atau pengelolaan air yang digunakan sebagai media tumbuh tanaman dan juga sebagai tempat akar tanaman menyerap unsur hara yang diperlukan dimana budidaya tanamannya dilakukan tanpa menggunakan tanah sebagai media tanamnya. Diunduh dari http://www.tipsberkebun.com/hidroponiknft.html pada hari Senin, 6 Juli 2015 
sistem NFT, sedangkan untuk cabe dan tomat, strobery, melon menggunakan sistem fertigasi yang penyediaan nutrisinya menggunakan sistem timer.Pelajari $\mathrm{PH}$ air dan ppm nya yang berbeda untuk masing-masing tanaman.

Ketiga,Tentukan lokasi penanaman.Meskipun tidak ideal, setidaknya kita harus menemukan tempat yang pas untuk meletakkan tanaman kita di sekitar rumah kita.Apakah diteras rumah, samping kiri, kanan, lantai atas rumah, dan lain-lain.Hal ini sangat penting karena lokasi sangat menentukan bagi tumbuh berkembangnya tanaman sampai panen. Misalnya saat menanam selada dan bayam, kol tidak masalah meskipun diletakkan pada tempat yang ternaungi karena membutuhkan cahaya matahari yang sedikit setidaknya 4 jam, lain halnya dengan tanaman cabe, tomat, sawi, yang setidak nya membutuhkan cahaya sekitar 6 - 8 jam sehari. Lainhalnya untuk menanam cabe paprika, strobery yang membutuhkan udara sejuk akan berbeda dengan menanam cabe dan tomat yang ditanaman di dataran rendah yang ber udara panas.

Keempat, Antisipasi hama dan gangguan pada tanaman.Tanaman hidroponik dapat diletakkan dimana saja di sekitar rumah anda. Apakah benar-benar tanaman kita aman dari gangguan sekitar.Saat pembenihan tanaman masih kecil ada kemungkinan tanaman anda di serang tikus, ayam tetangga, atau mungkin penyebab lainnya.Pada saat tanaman anda sudah mulai membesar dan mulai berbunga, apabila anda menggunakan sistem wick. Ada juga kemungkinan air yang panas dan gangguan jamur yang menyebabkan busuk akar, air tandon berlumut yang mengganggung sistem perakaran tanaman,pengguna sistem NFT harus mengantisipasi saat pompa air mati karena pemadaman listrik, serangan hama seperti serangga, jamur, berubahnya sistem nutrisi air dari kepekatan dan ph air, semua harus diantisipsi sedini mungkin, sehingga tanaman anda tetap sehat sampai panen.

Dari proses pelatihan dan pendampingan tersebut, maka diharapkan dapat terealisasi solusi permasalahan sebagaimana 
disebutkan di awal, yakni menjembatani persoalan yang dihadapi atau bakal dihadapi para santri terutama dalam hal perekonomian atau mata pencaharian. Hal ini dapat diilustrasikan sebagai berikut:

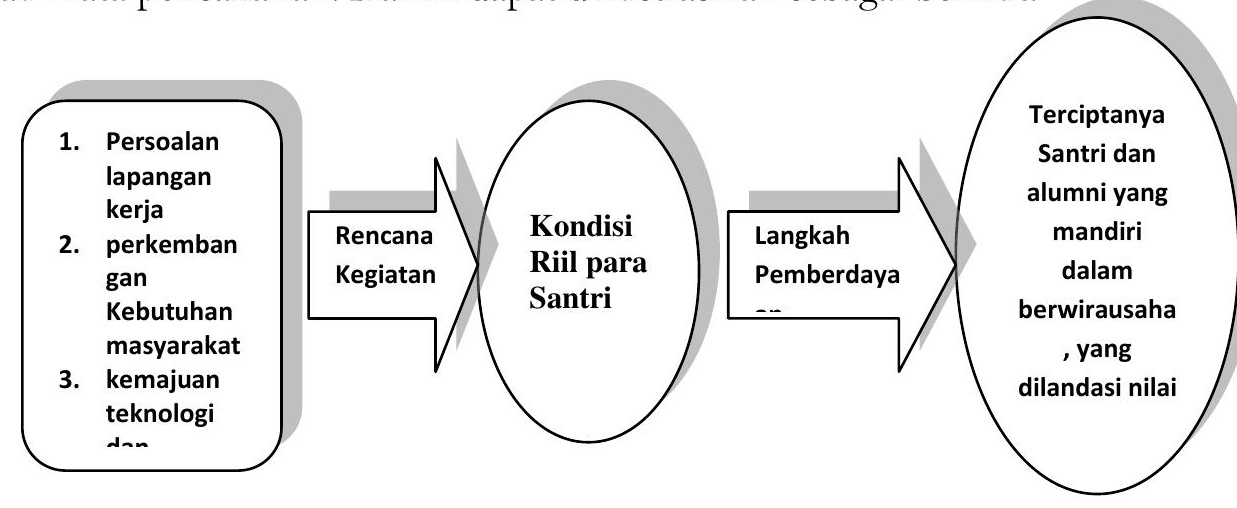

\section{KESIMPULAN DAN REKOMENDASI}

Dari pembahasan di atas dapat diambil beberapa kesimpulan. Pertama, Seiring dengan perkembangan zaman dan tuntutan kehidupan, khususnya di bidang ekonomi, pada dasarnya para santri membutuhkan pendamping dalam rangka menggali dan menumbuh-kembangkan minat, bakat dan potensi wirausaha mereka. Kedua, Dengan bekal pengetahuan agama Islam melalui berbagai pembelajaran kitab kuning di pesantren dan pembelajaran kemasyarakatan di dalamnya, para santri memiliki potensi untuk menjadi wirausahan yang jujur, amanah dan mandiri dan memiliki jaringan yang luas.

Ketiga, para santri perlu dibekali dengan berbagai pelatihan ketrampilan yang dapat mendukung pada kegiatan ekonomi mereka setidaknya yang dapat membuka peluang ekonomi mereka. Setidaknya, ada tiga pelatihan yang telah diberikan kepada para santri di tiga pondok pesantren; pondok pesantren Miftahul Falah, Pondok Pesantren ARIS, dan pondok pesantren ASPIR di bidang kewirausahaan tersebut; 1) Pembuatan makanan yang berasal dari kedelai dengan berbagai variasinya dan dari non-kedelai; 2) Pembuatan sulam pita pada kain; 3) pemanfaatan lahan kosong untuk kepentingan bisnis. Pelatihan-pelatihan tersebut mendapat respon posistif dari para peserta. Di samping antusias untuk 
mengikuti pelatihan tersebut, mereka juga sangat semangat untuk mempraktekkan materi-materi pelatihan tersebut.

Keempat, di samping memberi bekal ketrampilan yang memadai, hal yang lebih penting lagi adalah melakukan pendampingan melalui evaluasi dan monitoring. Berdasarkan monitoring yang dilakukan oleh Tim KPD, banyak santri/ peserta yang berminat untuk menindaklanjuti. Ada beberapa peserta yang membuat susu kedelai, misalnya, dan berusaha untuk memasarkannya. Ada yang dititipkan ke koperasi, ada juga yang mencoba untuk dipasarkan. Demikian pula, pembuatan sulam pita juga telah banyak dilakukan oleh para peserta, beberapa peserta telah mampu membuat dan untuk digunakan sendiri, bahkan ada yang dititipkan di koperasi-koperasi dan beberapa toko kerudung di Kaliwungu. Untuk pemanfatan lahan, pesantren ARIS telah menindaklanjutinya, meskipun belum maksimal.

Berdasarkan paparan dan kesimpulan di atas, ada beberapa rekomendasi yang dapat disampaikan. Pertama, hendaknya pemerdayaan masyarakat berbasis pesantren ini dilakukan lebih panjang waktunya, mengingat jadwal belajar santri cukup padat dan masing-masing pesantren memiliki jadwal yang berbeda-beda. Kedua, ada program pendampingan lanjutan, sebab, perlu lebih dilakukan secara intensif, terutama dalam hal pengemasan dan pemasaran barang produksi. Ketiga,untuk memaksimalkan program pengabdian, perlu pemetaan yang lebih intensif. Keempat, perlu peningkatan jejaring agar lebih memaksimalkan hasil pengabdian.

\section{DAFTAR PUSTAKA}

\section{A. Buku Dan Jurnal}

Abdillah, Masykuri, "Status Pendidikan Pesantren Dalam Sistem Pendidikan Nasional" dalam Kompas, Jum'at, 8 Juni 2001 Abdullah, Muhammad (ed), 2001, Menyoal Kota Santri Kaliwungu; Sebuah Ikbtiar Berkaca Diri, Kendal: Panitia Festival AlMuttaqin IV Kaliwungu. 
Ali, A.Mukti, Beberapa Persoalan Agama DewasaIni, (Jakarta: Rajawali Press, 1997).

Al-Quran Digital, 2015

Baladina, Nur, Membangun Konsep Enterpreunership Islam, dalam Jurnal Ulul Albab, volume 13 No 2 Tahun 2012.

Bruinessen, Martin van, KitabKuning, PesantrendanTarekat: Tradisitradisi Islam di Indonesia, (Bandung: Mizan, 1999)

Bull, Ronald Alan Lukens, Jihad Ala Pesantren di Mata antropolog Amerika, (Yogyakarta: Gama Media, 2004)

Dhofier, Zamakhsyari, TradisiPesantren: Studitentang Pandangan Hidup Kyai, (Jakarta: LP3ES, 1982)

ElFiky, Ibrahim, Dr, Terapi Berpikir Positif; Biarkan Mukjizat Dalam Diri Anda Melesat Agar Hidup Lebih Sukses Dan Lebih Bahagia, (Jakarta: Zaman, 2008) , Memperbaiki Nasib, Terapi Mengendalikan Diri Agar Hidup Terus LebihBaik, (Jakarta: Zaman, 2011)

Berpetualang Meledakekan Potensi Diri Untuk Hidup Lebih Cemerlang,(Jakarta: Zaman, 2014)

Fauzia, Ika Yunia, Dr, Lc, M.E.I dan Dr. Abdul Kadir Riyadi, Lc, MS.Sc, Prinsip Dasar Ekonomi Islam; Perspektif Maqashid alSyari'ah, (Jakarta: Kencana Prenadamedia Group, 2014)

Fitri, Ahmad Asrof, Agar Uang yang Mengejar Anda, (Yogyakarta: Real Books,2014)

Haedari, HM Amin, Masa Depan Pesantren dalam Tantangan Modernitas dan Tantangan Komplesitas Global, (Jakarta: IRD Press, 2004).

IAIN Syarif Hidayatullah, Ensiklopedi Islam Indonesia,(Jakarta: Djambatan, 1992).

M Quraisy Shihab, Membumikan Al-Quran, (Jakara: Mizan, 1991).

Mahfudh,KH. Sahal, Nuansa Figh Sosial, (Yogyakarta: LkiS, 1994)

Maksum, Dr.H, Madrasab; Sejarah dan Perkembangannya, Jakarta: Logos Wacana Ilmu, 1999)

Mas'ud, Abdurrahman, Sejarah dan Budaya Pesantren,dalam Ismail, dkk.(ed.), dinamika Pesantren dan Madrasah, (Yogyakarta: Pustaka Pelajar, 2002)

Masyhud, Sulthon, Drs, H.M., M.Pd, Drs. Moh. Khusnurdilo dkk, M.Pd, Manajemen Pondok Pesantren, Jakarta: Diva Pustaka, 2004) 
Moerdiyonodkk, Teknologi Tepat Guna untuk Wanita Pedesaan, Jakarta: Kantor Menteri Muda Urusan Peranan Wanita dan UNICEF, 1981)

Prasodjo, Sudjono, Profil Pesantren, (Jakarta: LP3S, 1982)

Purwadi, Budi, SE, MBA, Big Success Strategy; Panduan Lengkap Motivasi, Rencana Aksi, Stratetgi dan Evaluasi, (Jakarta: PT Gramedia Pustaka Utama, 2012)

Raharjo, M Dawam (peny.), Pesantren dan Pembaharuan, Jakarta: LP3S, 1985)

Rasyid, Sudrajat, dkk., Kewirausahaan Santri , Jakarta: PT. Citrayudha, 2005)

Steenbrink, Karel A, Pesantren, Madrasah, Sekolab; Pendidikan Islam dalam Kurun Modern (Jakarta:LP3S, 1986)

Suryanegara, Ahmad Mansur, Menemukan Sejarab: WacanaPergerakan Islam di Indonesia, (Bandung: Mizan, 1995)

Thoha, Zaenal Arifin, Runtubnya Singgasana Kiai; NU, Pesantren dan Kekuasaan, (Yogyakarta: Kutub, 2003)

Toyib, Masud, Sunan Katong dan Paku Waja, Jakarta: Sangga Budaya, 1987)

Tri SiwiAgustina, Kewirausabaan; teoridanPenerapanpadawirausabadan UKM di Indonesia, (Jakarta: MitraWacana Media, 2015)

Triono, Bambang, Rina Noviani, Muhammad Rois, Kaya dari Rumab; Panduan Mengembangkan Bisnis dari Rumah (Industri Rumaban), (Jember: Cerdas Ulet Kreatif. 2015)

Veithzal Rivai, Prof. Dr, MBA dan Andi Buchari, Ir, MMIslamic Economics: Ekonomi Syariah Bukan Opsi, tapi Solusi, (Jakarta: Bumi Aksara, 2008)

Wahid, Abdurrahman dkk, Kontroversi Pemikiran Islam di Indonesia, (Bandung: Rosdakarya, 1993)

Wahid, Abdurrahman, Bunga Rampai Pesantren, Jakarta: Darma Bhakti,1399H)

Wahid, Abdurrahman, Menggerakekan Tradisi: Esai-esai Pesantren, (Yogyakarta: LkiS, 2001)

Yafie, KH Ali, Menggagas Fiqih Sosial; Dari Soal Lingkungan Hidup, Asuransi Hingga Ukhuwah, (Bandung: Mizan,1994)

Yin, Robert K, Prof. Dr., Studi Kasus; Desain dan Metode, (Jakarta, Raja Grafindo Persada, 2000)

Ziemek, Manfred, Pesantren dan Perubaban Sosial, Jakarta: P3M, 1986) 


\section{B. Website}

https://id.wikipedia.org/wiki/Pesantren diunduh pada hari Senin, 29 Juni 2015

http://hakamabbas.blogspot.com/2014/05/jenis-pondok-

pesantren.htmldiunduh Selasa, 30 Juni 2015

http://nurfahmiakhmad96.blogspot.com/2013/08/pengertian-

dan-manfaat-vertikultur.html pada hari Senin tanggal 6 Juli 2015

http://www.azzamrumahherbal.com/hidroponik/191-cara-

menanam-menggunakan-sistem-hidroponik.html diunduh pada hari Senin tanggal 6 Juli 2015.

https://harusketemu.wordpress.com/tag/hidroponik-sistem-wick/ diunduh pada hari Senin 6 Juli 2015

http://griyahidroponik.blogspot.com-/p/fertigasi.html diunduh hari Senin tanggal 6 Juli 2015

http://www.tipsberkebun.com/hidroponik-nft.html diunduh pada hari Senin , 6 Juli 2015

http://kbbi.web.id/kiai, diunduh sabtu, 1 Agustus 2015, jam 09.34 http://kbbi.web.id/pemberdayaan, diunduh sabtu, 1 Agustus 2015, jam 09.45

http://kbbi.web.id/santri, diunduh sabtu, 1 Agustus 2015, jam 09.37

http://kbbi.web.id/usaha diunduh sabtu, 1 Agustus 2015, jam 09.40

http://kbbi.web.id/wira, diunduh sabtu, 1 Agustus 2015, jam 09.39 https://ponpesaskhabulkahfi.wordpress.com/metode-

pembelajaran/diunduh sabtu, 8 Agustus 2015, jam 15.30

http://doninovalinda.blogspot.com/2012/03/cara-membuat-

sulam-pita.html diunduh pada hari Ahad, 9 Agustus 2015 